\title{
THE MACROSCOPIC CYANOBACTERIUM NOSTOC PARMELIOIDES IN SWIFT CURRENT CREEK, SK, CANADA
}

John R. Lawrence

Environment and Climate Change Canada 11 Innovation Blvd.

Saskatoon, SK S7N $3 \mathrm{H} 5$

306-975-5789

John.Lawrence2@canada.ca

\section{Julie Roy}

Environment and Climate Change Canada 11 Innovation Blvd.

Saskatoon, SK S7N 3H5

306-975-5789

\section{George D.W. Swerhone}

Environment and Climate Change Canada 11 Innovation Blvd.

Saskatoon, SK S7N 3H5

\section{Armelle Paule}

Global Institute for Water Security University of Saskatchewan Saskatoon, SK

Although cyanobacteria or "bluegreen algae" are diverse and very common in Saskatchewan lakes, ponds and rivers they are for the most part only apparent when they form visible blooms, scums or large colonies. This is the case for a variety of common types of these photosynthetic bacteria - including Aphanizomenon spp., which may form characteristic colonies with the appearance of grass clippings or Microcystis spp., which typically form macroaggregates with gas vesicles allowing them to float and be visible in the open water.

However, several cyanobacteria can form colonies in streams large enough to be considered macroalgae. In general, these colonies are attached to substrata such as cobbles or large rocks and form structures easily visible to the naked eye ${ }^{1,2}$. Several members of the cyanobacterial genus Nostoc form a variety of types and shapes of macrocolonies in freshwaters including: $N$. caeruleum, $N$. commune, N. microscopicum, $N$. pruniforme, $N$. verrucosum and $N$. zetterstedtii. $^{3}$

One common macrocolony former is Nostoc parmelioides which was first described in 1830 growing attached to rocks in fast flowing, acidic $(\mathrm{pH}<7)$, cold $\left(4-5^{\circ} \mathrm{C}\right)$ streams in Germany and northern Europe. ${ }^{3}$ Nostoc parmelioides is differentiated

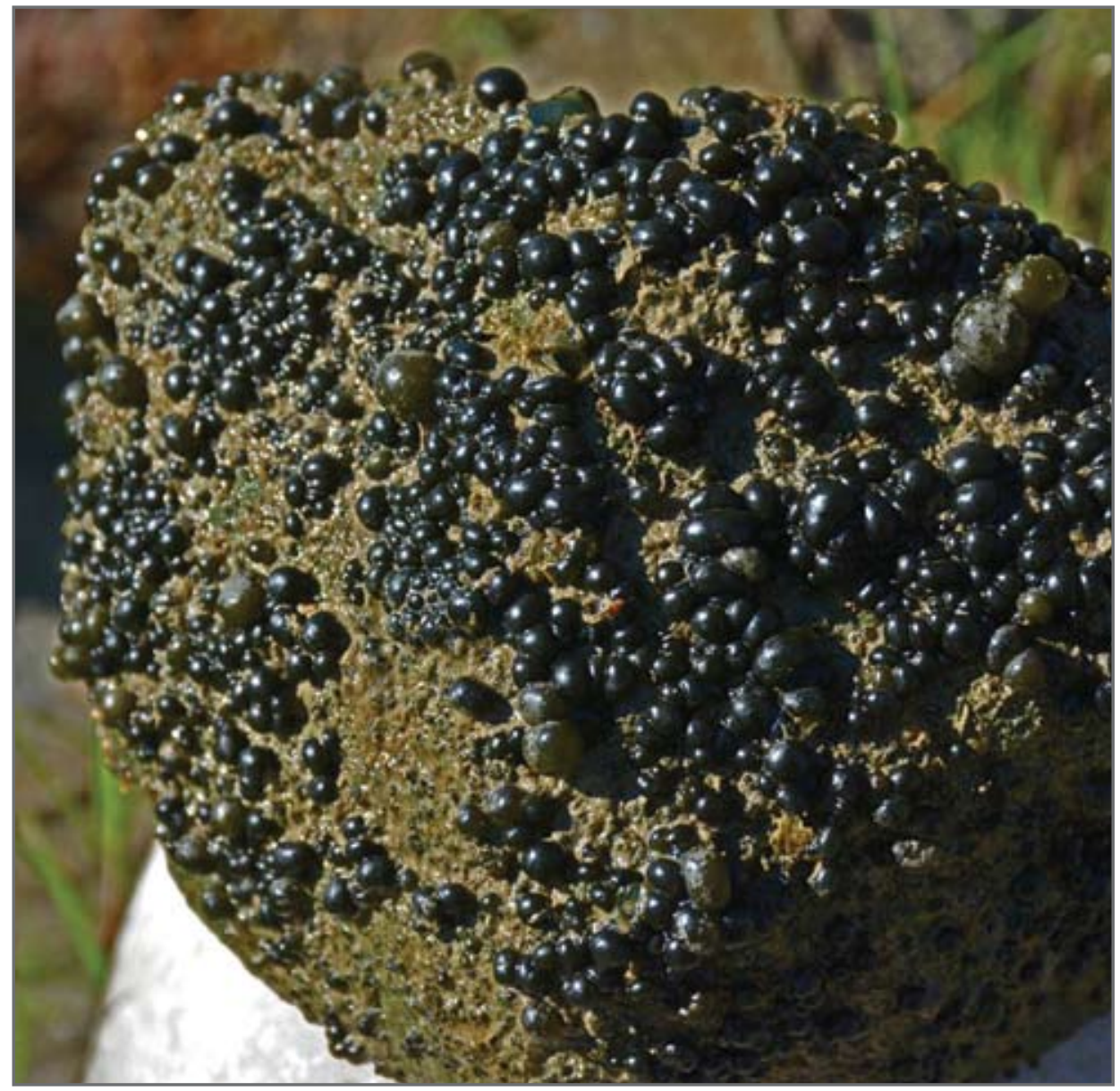

FIGURE 1. Rock from Swift Current River, showing a typical array of macrocolonies with a range of coloration from near black to dark blue-green, less than $1 \mathrm{~cm}$ in diameter and frequently arranged in tight masses. Photo credit: Julie L. Roy. members of this genus based on its discoid or spherical smooth surfaced thallus, which is variously described as ranging from 5 to $15 \mathrm{~mm}$ in diameter, or up to $350-700 \mathrm{~mm}$, which is consistent with observations at Swift Current Creek. ${ }^{3,4,5}$

Microscopic examination of the thallus revealed the presence of akinetes and vegetative cells typical of Nostoc parmelioides ${ }^{6}$ (subsequently it has been described from a wide variety of habitats, including streams of the tundra, coastal plains, coniferous forest, from the other macroscopic 
hardwood forest, tropical rain forest, boreal forest, and desert chaparral'1). In North America, N. parmelioides has been found in fast flowing streams that are seasonally warm $\left(+20^{\circ} \mathrm{C}\right)$, alkaline $(\mathrm{pH}>8.3)$ and more nutrient rich. ${ }^{1}$ Although N. parmelioides appears widely distributed, it has not been described from streams in the northern prairie grasslands.

In their survey, Sheath and Cole (1992) did not sample grasslands since they considered the habitat to have a "high degree of disturbance". ${ }^{1}$ The genus forms typical "spherical" structures anchored to the rock surface, generally dark blue green in colour and up to $1 \mathrm{~cm}$ in diameter but range, depending upon age and habitat, from microscopic initial colonies to large masses of colonies on the rock surface.

Figure 1 illustrates a typical array of colonies that are in general much less than $1 \mathrm{~cm}$ in diameter and frequently appear as tightly arranged masses. The site in Swift Current Creek (50³6'4.41 "N,
10743'28.80"W -Hwy 738) was typical of many North American habitats in terms of high light levels, rapid water flow, $\mathrm{pH} 8.4$, summer temperatures exceeding $20^{\circ} \mathrm{C}$ and the presence of large rocks (Figure 2).

At some locations in North America, N. parmelioides has an interesting relationship with the fly larvae Cricotopus spp. that lives inside the macrocolony structure, tunneling through it and creating a colony type described as an earshaped flattened structure compared to the spherical ball typical of the colony. ${ }^{7}$ We did not observe this phenomenon in Swift Current Creek, although it has been reported in streams in Oregon. ${ }^{8}$

In conclusion, these observations provide a record of this species in a grassland biome with a range extension into southern Saskatchewan.

\section{References}

1. Sheath RG, Cole KM (1992) Biogeography of stream macroalgae in North America. Journal of Phycology 28:448-60.

2. Dodds WK, Gudder DA, Mollenhauer D
(1995) The ecology of Nostoc: Review. Journal of Phycology 31:2-18.

: 3. Mollenhauer D, Bengtsson R, Lindstrøm E-A (1999) Macroscopic cyanobacteria of the genus Nostoc: a neglected and endangered constituent of European inland aquatic biodiversity. European Journal of Phycology 34:349-360.

4. Holmes, N.T.H., Whitton, B.A. (1975). Notes on some macroscopic algae new or seldom recorded for Britain: Nostoc parmelioides, Heribaudiella fluviatilis, Cladophora aegagropila, Monostroma bullosum, Rhodoplax schinzii. Vasculum 60:47-55

5. Mollenhauer D, Budel B, Mollenhauer $R$, (1994) Approaches to species delimitations in the genus Nostoc Vaucher (1803 ex Bornet et Flahault-1888). Algological Studies 75:189-209.

6. Bornet, E. Flahault, C. (1886-88) Revision des Nostocacees heterocystees. Ann. Sci. Nat. Bot. 7th series 3, 4, 5, 7: 323-380, 343-373, 51-129, 171-262.

7. Brock EM (1960). Mutualism between the midge Cricotopus and the alga Nostoc. Ecology 41:474-83.

8. Dodds WK, Marra JL (1989) Behaviors of the midge, Cricotopus (Diptera: Chironomidae) related to mutualism with Nostoc parmelioides (Cyanobacteria). Aquatic Insects 11:201-208.

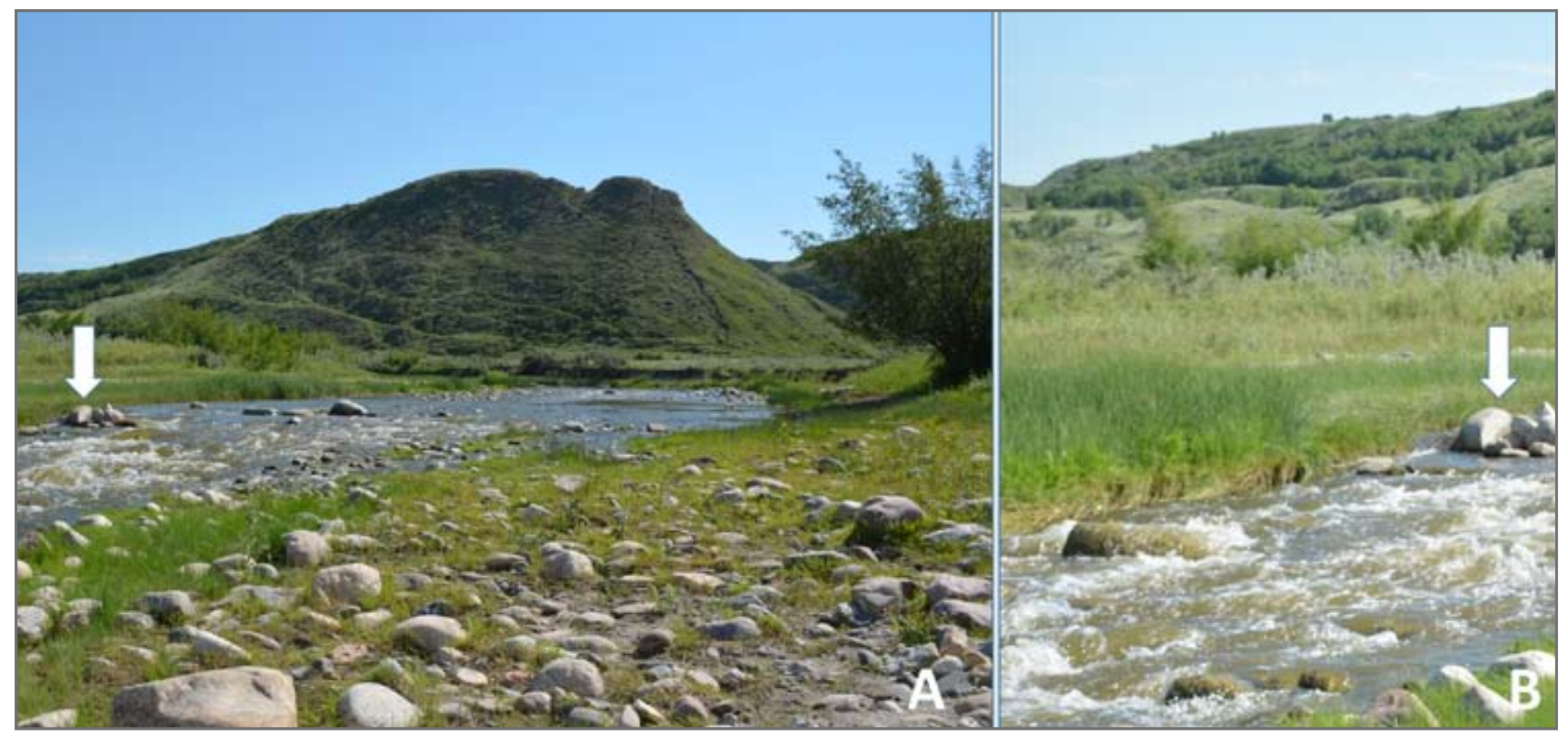

FIGURE 2. The site in Swift Current Creek (50³6 $4.41^{\prime \prime} \mathrm{N}, 107^{\circ} 43^{\prime} 28.80^{\prime \prime} \mathrm{W}$-Hwy 738 ) illustrating the habitat with high light levels, rapid water flow and

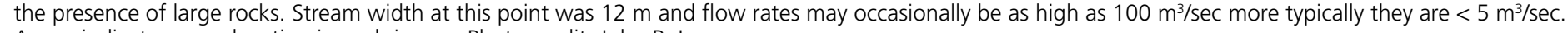
Arrow indicates same location in each image. Photo credit: John R. Lawrence 